\title{
A Diabetes Self-Management Education/Support (DSME/S) Program in Reference to the Biological, Psychological and Social Aspects of a Patient with Type 2 Diabetes Mellitus: A Systematic Review
}

\author{
Novita Fajriyah, Tria Anisa Firmanti, Ainul Mufidah and Nita Tri Septiana \\ Faculty of Nursing, Universitas Airlangga, Surabaya, Indonesia
}

\begin{abstract}
Introduction: Various efforts have been made to improve the self-care management of patients with type 2 diabetes mellitus (T2DM). One of them is by using a Diabetes Self-Management Education and Support (DSME/S) program. DSME/S produces positive effects in relation to patient behavior and health status. This is a systematic review of randomized controlled trials published where the aim was to evaluate the impact of the DSME/S program in term of biological. psychological and social aspects.
\end{abstract}

Methods: The articles were searched for using the PRISMA approach from within Scopus, Sage Journal, ProQuest, Google Scholar and PubMed to identify the relevant English publications on DSME over the last 5 years (2013-2018). In total, 15 studies met the inclusion criteria.

Results: The articles included at least one result that covered the biological, psychological, and social aspects that are more general and relevant for T2DM patients who received the DSME program. DSME had a positive impact on T2DM, namely the reduction of HbA1c, blood glucose, LDL, cholesterol, blood pressure, weight, waist circumference, decreased distress, anxiety and increased self-efficacy and self-empowerment.

Conclusion: It can increase the social and family support, improve selfmanagement motivation, increase knowledge and improve the behavior of T2DM patients. The findings of our review showed that DSME has a positive impact on the biological, psychological and social aspects of type 2 diabetes mellitus.

\section{ARTICLE HISTORY}

Received: Dec 26, 2019

Accepted: Dec 31, 2019

\section{KEYWORDS}

diabetes self-management education and support; type 2 diabetes mellitus; biological; psychological; social

\section{CONTACT}

Tria Anisa Firmanti

$\triangle$ tria.anisa.firmanti2018@fkp.unair.ac.id

$\Xi^{\prime}$ Faculty of Nursing, Universitas Airlangga, Surabaya, Indonesia

Cite this as: Fajriyah, N., Firmanti, T. A., Mufidah, A., \& Septiana, N. T. (2019). A Diabetes Self-Management Education / Support (DSME/S) Program in Reference to the Biological, Psychological and Social Aspects of a Patient with Type 2 Diabetes Mellitus: A Systematic Review.Jurnal Ners, 14(3si), 55-64. doi:http://dx.doi.org/10.20473/in.v14i3(si).16979

\section{INTRODUCTION}

One of the health challenges of society in this world is diabetes mellitus (DM). This is the fifth most common cause of death in high-income countries, and it is rapidly becoming an epidemic in low- and mediumincome countries. Expensive diabetes care can cause serious complications such as kidney failure, myocardial infarction, stroke, blindness and the amputation of limbs (Kumah, Sciolli, Toraldo, \& Murante, 2018). One of the diseases that has become an epidemic in the world and its prevalence in terms of increase is type 2 diabetes. According to the WHO in 2016, the biggest percentage of diabetes is type 2 diabetes, which is $95 \%$ with weight loss problem and psychological disorders.

Approximately 415 million diabetics are aged 20 79 years and according to the International Diabetes Federation in 2015, this number will increase to 642 million in 2040. According to the WHO in 2011, there are 12.3 million diabetics in Southeast Asia and this is estimated to increase to 19.4 million in 2040 . According to the WHO in 2009 , the prevalence of diabetics was $8,246,000$. In 2000, Indonesia was ranked first in Southeast Asia and it is estimated to increase by 2.5 times, which is as many as $21,257,000$ by 2030 . According to the Ministry of Health 2013, the highest symptoms of DM prevalence were found in 
Central Celebes 3.7\%, North Celebes 3.6\%, South Celebes 3.4\% and East Nusa Tenggara 3.3\%. Based on the doctor's diagnosis, the highest prevalence of DM was found in DI Yogyakarta 2,6\%, DKI Jakarta 2.5\%, North Celebes 2.4\% and East Borneo 2.3\%. The proportion of the Indonesian population aged $>15$ years with DM is 6.9\% (Kementrian Kesehatan RI, 2018).

Type 2 diabetes mellitus is a type of diabetes that is characterized by an increase $\mathrm{n}$ blood sugar due to a decrease in insulin secretion by the pancreatic beta cells and / or impaired insulin function (insulin resistance). Type 2 diabetes mellitus can be seen from the increased blood sugar levels during fasting, glycemic control and significant weight loss. Incorrect perceptions due to a lack of knowledge of type 2 diabetics causes psychological effects and an inability to treat themselves, so many patients experience depression (Farhangi, 2017).

Epidemiological trends indicate that the prevalence of type 2 diabetes mellitus is expected to increase continuously in the coming years due to unhealthy behavior, the enhancement of urbanization, the reduction of physical activity, dietary changes and increased obesity. The risk factors that cannot be changed are gender, age and genetic factors. The changeable risk factors are smoking, alcohol consumption, physical activity, knowledge and obesity. If good management is not focused on these risk factors, then it can cause nursing problems in the biological, psychological and psychosocial aspects (Costa, 2016).

The self-care management education program is a systematic intervention involving active patient participation in self-monitoring and / or decision making, providing diabetic patients with the knowledge and skills needed to carry out self-care behavior, allowing them to manage crises and to make effective lifestyle changes (Cai \& Hu, 2016). Several empirical studies have shown that the DSME / S program has a beneficial effect on patient health, health behavior and the utilization of health services which reduces the medical costs for treating diabetics. A systematic review also showed an improvement of the outcomes such as better glycemic control, increased weight loss, increased knowledge, the reduction of blood pressure, the increase in diet and exercise habits, and the reduction of the need for diabetes medication.

In a research article entitled '2017 National Standards for Diabetes Self-Management Education and Support', DSME / S is stated as being a process that facilitates the knowledge, skills and abilities of diabetics to care for themselves. The activities that are described refer to the help from others that can support them in their daily needs in terms of regulating their condition continuously from the baseline to the end or even when outside of the selfmanagement training.(Beck et al., 2018) The available evidence indicates that early diagnosis and effective management can improve the prevention of complications, and improve the client's condition, especially in the biological, psychological and social aspects (García, Brown, Horner, Zuñiga, \& Arheart, 2014). Among the management strategies, patient education programs are considered to be the components of effective and efficient care for type 2 diabetes as a prevention strategy against complications (Busch et al., 2015; Cai \& Hu, 2016; Chrvala, Sherr, \& Lipman, 2016).

Evidence from the randomized controlled trials and observational studies suggest that DSME is costeffective at improving the lifestyle, clinical, and psychosocial outcomes (Azami et al., 2018). It is associated with favorable changes in knowledge (Albikawi, Petro-Nustas, \& Abuadas, 2016; Cai \& Hu, 2016; García et al., 2014), clinical outcomes (Ku \& Kegels, 2014), self-efficacy, self-management and other psychosocial outcomes (Cai \& Hu, 2016; Chai et al., 2018; Habibzadeh, Sofiani, Alilu, \& Gillespie, 2017; Yuan et al., 2014), in addition to quality of life (Cai \& $\mathrm{Hu}, 2016$; Chai et al., 2018; Kim et al., 2015; Ku \& Kegels, 2014).

Several studies were used as systematic reviews related to DSME / S and type 2 diabetes as an effort to improve glycemic control, blood sugar, psychological problems such as stress, anxiety, and distress, and to improve knowledge, the self-care ability and to improve patient perceptions about the disease. This was a systematic review of the randomized controlled trials published to evaluate the impact of the DSME program in terms of the biological, psychological, and social aspects.

\section{MATERIALS AND METHODS}

We focused our analysis on studies that evaluated the effectiveness of Diabetes Self-Management Education /Support (DSME/S) and the holistic aspects of Type 2 Diabetes. This is because the program is known to produce more positive effects that counter the risk of long-term complications.

We used four steps to identify and select journals that met the criteria specified in this review (Figure 1). Firstly, we conducted a major search on the chosen databases (Scopus, Sage Journal, Proquest, Science Direct, and Pubmed) to identify the relevant English works published in the last 5 years (2013-2018). For this review, we used the following search string: (Diabetes* OR Diabetes Mellitus) AND (Diabetes SelfManagement Education* DSME* OR * Diabetes SelfManagement Support* OR DSMS*) AND (patient* OR person *) AND (benefit* OR effectiveness * OR results *) AND (Self-Management Education* OR SelfManagement Support* OR education* OR intervention * OR program*) AND (glucose level* OR HbA1C* OR Self-Efficacy* OR Quality of Life* OR Glycemic control * OR Stress* OR Distress* OR Psychology* OR Behavior*). The search identified a total of 1325 articles but the number of articles was reduced to 885 after removing the duplicate results. Secondly, to identify eligible journals, we carefully read each title and abstract of the 885 journals. We focused on three main criteria, namely as the journal 


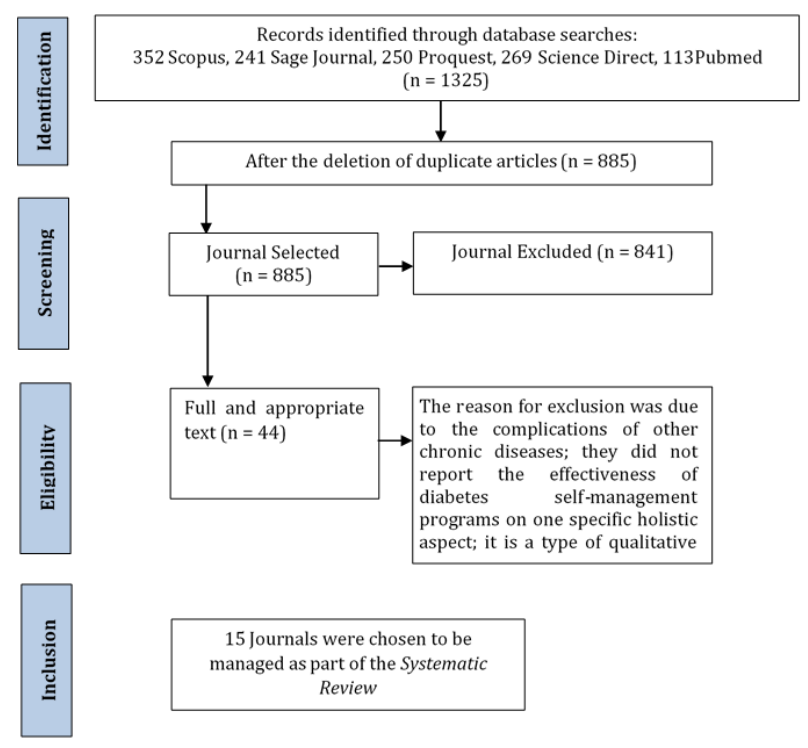

Figure 1. Literature search flow

population compiled consisted of Type 2 Diabetes Mellitus patients. The journals focused on the effectiveness of the Diabetes Self-Management Education (DSM) program and Diabetes SelfManagement Support (DSMS), and the journal reported the results of the Diabetes Self-Management Education (DSME) and Diabetes Self-Management Support (DSMS). After this, 841 journals were to be included in the next stage of the review, because the journals had to be sure that they would meet all of the criteria needed.

Third, the remaining 44 journals were read and understood to be considered further for the inclusion criteria. In detail, the journal must not to be a review / report / protocol article, it must exclusively refer to type 2 diabetes mellitus, it must report at least one result which includes the biological, psychological, and social aspects that are more general and relevant for type 2 diabetes mellitus patients who receive the Diabetes Self-Management Education (DSME) program and Diabetes Self-Management Support (DSMS), such as hemoglobin glycated (HbA1C), Body Mass Index (BMI), diet, physical activity (diabetic foot exercises, etc.), mental health (psychology, stress, distress), self-efficacy, quality of life) and the utilization of the health services (glycemic control etc). The study should also be from an indexed and reputable journal.

After the third step, 29 articles were eliminated. The reason for exclusion was due to the complications of other chronic diseases. They did not report on the effectiveness of diabetes self-management programs on one specific holistic aspect. It was a type of qualitative research. Finally, the remaining 15 journals were considered to be eligible for review and analysis. All of them focused on the effectiveness of the Diabetes Self-Management Education / Support (DSME/S) program for type 2 diabetes mellitus patients focused on the biological, psychological, and social aspects.

For each journal that meets the requirements, the research team drew information about the study design, participant / sample, the type of intervention, the name of the Diabetes Self-Management Education / Support (DSME / S) program, the results of the study, the length of the program, the professional leader, the doctors, endocrinologists, nutritionists, pharmacists, registered dietitians and community health workers (CHWs) involved, the psychologists, public health experts, peer leaders, community health workers, registered dietitian nutritionists (RDN), physicians, medical teams, psychology and public health staff involved, and the location of the study (country).

In our analysis, we only considered the results of the Diabetes Self-Management Education / Support (DSME / S) program which included the biological, psychological, and social aspects. The effects of increase ( + ) and decrease ( - ) in terms of yield from DSME/S have been shown in each reported result.

\section{RESULTS}

The sample used in the study varied with the minimum sample being 19 with the maximum being 250 participants. The place where the research was conducted was in Asia for as many as four countries (Indonesia, Hong Kong, China, and Philippines). Three studies were located in the United States (USA), three studies were located in Iran and one study was located in Iraq, Canada, and Latin America. The complete explanation can be seen in Table 1 .

There were eight studies about pure DSME program, comparison between DSME and diabetes care standards and other programs. The leader program was carried out by professionals, while five studies were conducted by professional nurses, three studies were conducted by nurses who collaborated with other health professionals such as endocrinologists, nutritionists, pharmacists, registered dietitians, and community health workers, three studies were conducted by peer educators, and one of them was in collaboration with community health workers (CHWs). Two studies were conducted by a certificated nutritionist and a registered nutritionist (RDN), two studies were conducted by physicians, one study was conducted by a multidisciplinary team from the medicine, psychology, and public health sections. The duration of the intervention varied with the shortest being 2 months and the longest being 12 months. The details of each study have been explained in Table 1.

Problem Based Learning (PBL) Program. The Problem Based Learning (PBL) program is a program based on specific problem learning especially for patients with type 2 diabetes mellitus. This program can reduce anxiety, depression, decrease fasting blood glucose levels and $\mathrm{HbA} 1 \mathrm{c}$, and it improve 
Table 2. Experimental Studies and RCTs of DSME/S type 2 diabetes mellitus as the basis of the systematic review

\begin{tabular}{|c|c|c|c|c|c|c|c|}
\hline Author & $\begin{array}{l}\text { Type of } \\
\text { Study }\end{array}$ & Participant & Intervention & $\begin{array}{l}\text { Name of } \\
\text { Program }\end{array}$ & $\begin{array}{l}\text { Program } \\
\text { Leader }\end{array}$ & $\begin{array}{l}\text { Outcome and effect of } \\
\text { DSME/S } \\
\text { (+/increase and } \\
-/ \text { decrease })\end{array}$ & Time \\
\hline $\begin{array}{l}\text { (Chai et } \\
\text { al., 2018) }\end{array}$ & $\begin{array}{l}\text { Completel } \\
\text { y } \\
\text { randomiz } \\
\text { ed design }\end{array}$ & $\begin{array}{l}118 \\
\text { (intervention } \mathrm{n} \\
=63 \text { control } \mathrm{n} \\
=55)\end{array}$ & DSME & $\begin{array}{l}\text { Problem Based } \\
\text { Learning (PBL) }\end{array}$ & $\begin{array}{l}\text { Professional } \\
\text { nurse } \\
\text { educator }\end{array}$ & $\begin{array}{l}\text { 1.Primary result: } \\
\text { Hemoglobin A1c (-) } \\
\text { Glucose (-) } \\
\text { 2.Secondary result } \\
\text { Psychosocial (+) } \\
\text { Diabetes self- } \\
\text { management and health } \\
\text { education (+) }\end{array}$ & 6 months \\
\hline $\begin{array}{l}\text { (Cai \& Hu, } \\
\text { 2016) }\end{array}$ & $\begin{array}{l}\text { Quasi- } \\
\text { experime } \\
\text { ntal } \\
\text { design }\end{array}$ & $\begin{array}{l}57 \\
\text { (intervention } \\
n=29 \text { control } \\
n=28 \text { ) }\end{array}$ & $\begin{array}{l}\text { Family-based } \\
\text { self- } \\
\text { management } \\
\text { educational }\end{array}$ & DSME & $\begin{array}{l}\text { The first } \\
\text { writer is a } \\
\text { nurse (RN) }\end{array}$ & $\begin{array}{l}\text { Diabetes knowledge }(+) \\
\text { self-efficacy diabetes }(+) \\
\text { self-care activities }(+) \\
\text { Quality of life }(+)\end{array}$ & 3 months \\
\hline $\begin{array}{l}\text { (Kargar } \\
\text { Jahromi } \\
\text { et al., } \\
\text { 2014) }\end{array}$ & RCT & $\begin{array}{l}\mathrm{N}=90 \\
\text { (experimental } \\
\text { and control) }\end{array}$ & DSME & $\begin{array}{l}\text { Self-Care } \\
\text { Education }\end{array}$ & $\begin{array}{l}\text { The } \\
\text { researchers } \\
\text { are nurses }\end{array}$ & Quality of life (+) & $\begin{array}{l}2 \quad- \\
\text { months }\end{array}$ \\
\hline $\begin{array}{l}\text { (Azami et } \\
\text { al., 2018) }\end{array}$ & RCT & $\begin{array}{l}\mathrm{N}=142 \\
\text { (intervention= } \\
71 \quad \text { control } \\
\mathrm{n}=71 \text { ) }\end{array}$ & $\begin{array}{l}\text { A nurse-led } \\
\text { DSME }\end{array}$ & $\begin{array}{l}\text { Nurse-led } \\
\text { DSME } \\
\text { intervention }\end{array}$ & $\begin{array}{l}\text { Nurse and } \\
\text { team } \\
\text { (endocrinolo } \\
\text { gists, } \\
\text { nutritionists, } \\
\text { nurses, and } \\
\text { pharmacists } \\
\text { ) }\end{array}$ & $\begin{array}{l}\text { Clinical: } \\
\text { HbA1c (-) } \\
\text { Sekunder: } \\
\text { Blood pressure (-) } \\
\text { Weight (-) } \\
\text { Lipid profile (-) } \\
\text { Self-efficacy } \\
\text { (expectation of success } \\
\text { and expected results) } \\
(+) \\
\text { Self-management } \\
\text { behavior (+) } \\
\text { Quality of life (+) } \\
\text { Social support (+) } \\
\text { Psychology }(+)\end{array}$ & 2 months \\
\hline $\begin{array}{l}\text { (Abdulah } \\
\text { et al., } \\
2018)\end{array}$ & $\begin{array}{l}\text { A double- } \\
\text { arm post- } \\
\text { test } \\
\text { interventi } \\
\text { on study. }\end{array}$ & $\begin{array}{l}N=45 \text { (experim } \\
\text { ental arm }(n= \\
22) \text { and control } \\
\text { arm }(n=23)\end{array}$ & $\begin{array}{l}\text { Self- } \\
\text { Management } \\
\text { Education }\end{array}$ & $\begin{array}{l}\text { self- } \\
\text { management } \\
\text { health } \\
\text { education } \\
\text { (face to-face } \\
\text { group session) }\end{array}$ & Nurses & $\begin{array}{l}\text { Physical Activity(+) } \\
\text { DM Diet }(+) \\
\operatorname{HbA1c}(-)\end{array}$ & 3 months \\
\hline $\begin{array}{l}\text { (Kim et } \\
\text { al., 2015) }\end{array}$ & RCT & $\begin{array}{l}n \quad=\quad 250 \\
\text { (intervention } \\
\text { group } \mathrm{n}=120, \\
\text { control group } \mathrm{n} \\
=130 \text { ) }\end{array}$ & $\begin{array}{l}\text { self-help based } \\
\text { community } \\
\text { (SHIP-DM): } \\
\text { self-help } \\
\text { intervention } \\
\text { program } \\
\text { for diabetes } \\
\text { management } \\
\text { (SHIP-DM) }\end{array}$ & $\begin{array}{l}\text { self-help } \\
\text { intervention } \\
\text { program was } \\
\text { designed for } \\
\text { diabetes } \\
\text { management } \\
\text { (SHIP-DM) }\end{array}$ & $\begin{array}{l}\text { Nurses team } \\
\text { and } \\
\text { community } \\
\text { health } \\
\text { workers }\end{array}$ & $\begin{array}{l}\text { Clinical: } \\
\text { Hemoglobin A1c (-) } \\
\text { Glucose (-) } \\
\text { Total cholesterol (-) } \\
\text { LDL (-) } \\
\text { Secondary } \\
\text { Psychosocial (+) } \\
\text { Self-management } \\
\text { behavior (+) } \\
\text { Quality of life (+) } \\
\text { Self-efficacy (+) with } \\
\text { Compliance } \\
\text { therapy (+) }\end{array}$ & 12 months \\
\hline $\begin{array}{l}\text { (Rusdian } \\
\text { a et al., } \\
2018)\end{array}$ & $\begin{array}{l}\text { Quasi- } \\
\text { experime } \\
\text { ntal (One } \\
\text { Group } \\
\text { Pretest- } \\
\text { Posttest } \\
\text { Design) }\end{array}$ & $\mathrm{n}=80$ & DSME & DSME program & $\begin{array}{l}\text { Medical } \\
\text { team, } \\
\text { psychology, } \\
\text { public } \\
\text { health. }\end{array}$ & HbA1c Level (-) & 3 months \\
\hline
\end{tabular}

diabetes self-management and health for patients with type 2 diabetes mellitus (Chai et al., 2018).

Nurse-led DSME intervention. It is an educational program led by nurses as the educators. In this case, the patients were educated regarding selfmanagement in the self-care of patients with type 2 diabetes mellitus. The main outcome of the program was that it can reduce the $\mathrm{HbA1c}$ values. The secondary results were changes in blood pressure, body weight, lipids, self-efficacy, self-management behavior, quality of life, social support and psychology (Azami et al., 2018).

Self-Help Intervention Program Was Designed for Diabetes Management. The intervention was designed to help type 2 diabetes mellitus patients to perform treatments independently. The aim of this program was to help the patients achieve better glycemic control and to restore their confidence in the 
Table 2. Experimental Studies and RCTs of DSME/S type 2 diabetes mellitus as the basis of the systematic review (Continue)

\begin{tabular}{|c|c|c|c|c|c|c|c|}
\hline Author & $\begin{array}{l}\text { Type of } \\
\text { Study }\end{array}$ & Participant & Intervention & $\begin{array}{l}\text { Name of } \\
\text { Program }\end{array}$ & $\begin{array}{c}\text { Program } \\
\text { Leader }\end{array}$ & $\begin{array}{c}\text { Outcome and effect of } \\
\text { DSME/S } \\
\text { (+/increase and } \\
\text {-/decrease })\end{array}$ & Time \\
\hline $\begin{array}{l}\text { (Yuan et } \\
\text { al., 2014) }\end{array}$ & RCT & $\begin{array}{l}n=76 \text { patients } \\
\text { (intervention } \\
n=36 \text {, control } \\
n=40 \text { ) }\end{array}$ & DSME & $\begin{array}{l}\text { DSME } \\
\text { program }\end{array}$ & $\begin{array}{l}\text { A } \\
\text { certificated } \\
\text { nutritionis } \\
\mathrm{t}\end{array}$ & $\begin{array}{l}\text { Short term education }(+) \\
\text { Knowing DSME in metabolic } \\
\text { and parameter cases } \\
\text { aterosclerotic: } \\
\text { HbA1c }(-) \\
\text { Obesity (-) }\end{array}$ & 3 months \\
\hline $\begin{array}{l}\text { (García } \\
\text { et al., } \\
\text { 2014) }\end{array}$ & RCT & $\begin{array}{l}72 \text { patient } \\
\text { (36 } \\
\text { intervention } \\
\text { group, } 36 \\
\text { control group) }\end{array}$ & DSME & DSME & Nurses & $\begin{array}{l}\text { Clinical: } \\
\text { HbA1c (-) } \\
\text { Clinical symptoms (-) } \\
\text { Lipid Levels (-) } \\
\text { Blood Pressure (-) } \\
\text { Cholesterol (-) } \\
\text { LDL (-) } \\
\text { BMI (Body Mass Index) (+) } \\
\text { Psychosocial } \\
\text { Diabetes Knowledge }(+) \\
\text { Self Efficacy(+) } \\
\text { Empowerment }(+) \\
\text { Positive behavior changes } \\
(+) \\
\text { Quality of } \\
\text { management }(+) \\
\text { Quality of Life }(+)\end{array}$ & $\begin{array}{lll}2 \quad- & 6 \\
\text { months }\end{array}$ \\
\hline $\begin{array}{l}\text { (Habibza } \\
\text { deh et al., } \\
2017 \text { ) }\end{array}$ & RCT & $\begin{array}{l}90 \text { patients ( } 45 \\
\text { intervention, } \\
45 \text { control) }\end{array}$ & $\begin{array}{l}\text { Group } \\
\text { Discussion }\end{array}$ & $\begin{array}{l}\text { Group } \\
\text { Discussion- } \\
\text { based } \\
\text { Education on } \\
\text { Self- } \\
\text { management }\end{array}$ & Nurses & Self-management $(+)$ & 3 months \\
\hline $\begin{array}{l}\text { (Adam et } \\
\text { al., 2018) }\end{array}$ & $\begin{array}{l}\text { Mixed } \\
\text { methods } \\
\text { (pretest/ } \\
\text { post-test } \\
\text { design) }\end{array}$ & $\begin{array}{l}\mathrm{N}=21 \quad(\mathrm{CM} \\
\text { intervention } \\
\mathrm{n}=10 \quad \mathrm{TE} \\
\text { intervention } \\
\mathrm{n}=11)\end{array}$ & $\begin{array}{l}\mathrm{CM}-\mathrm{TE} \\
\text { intervention }\end{array}$ & $\begin{array}{l}\text { traditional } \\
\text { education } \\
\text { (TE) } \\
\text { Canadian } \\
\text { conversation } \\
\text { maps (CMs) }\end{array}$ & Nurses & $\begin{array}{l}\text { Clinical : } \\
\text { HbA1c }(-) \\
\text { Psychosocial : } \\
\text { Knowledge of DM } \\
\text { management }(+) \\
\text { Attitude }(+)\end{array}$ & 3 months \\
\hline $\begin{array}{l}\text { (Ku \& } \\
\text { Kegels, } \\
\text { 2014) }\end{array}$ & $\begin{array}{l}\text { Prospecti } \\
\text { ve quasi- } \\
\text { experime } \\
\text { ntal }\end{array}$ & $\begin{array}{l}\mathrm{N}=164 \text { (108 in } \\
\text { Batac City and } \\
59 \text { in } \\
\text { Pagudpud) }\end{array}$ & $\begin{array}{l}\text { FiLDCare } \\
\text { Project } \\
\text { DSME/S }\end{array}$ & $\begin{array}{l}\text { FiLDCare } \\
\text { Project } \\
\text { DSME/S }\end{array}$ & $\begin{array}{l}\text { the LGHU } \\
\text { nurse } \\
\text { the } \\
\text { FiLDCare } \\
\text { Project } \\
\text { nurse }\end{array}$ & $\begin{array}{l}\text { Clinical } \\
\text { HbA1c }(-) \\
\text { Waist circumference }(-) \\
\text { Psychosocial } \\
\text { Knowledge of DM } \\
\text { management }(+) \\
\text { Attitude }(+) \\
\text { Diet compliance }(+)\end{array}$ & 12 months \\
\hline $\begin{array}{l}\text { (Spencer } \\
\text { et al., } \\
\text { 2018) }\end{array}$ & $\begin{array}{l}\text { Comparat } \\
\text { ion }\end{array}$ & $\begin{array}{l}\mathrm{N}=222 \\
(\mathrm{CHW}+\mathrm{PL} \\
\mathrm{n}=60, \quad \mathrm{CHW} \\
\text { only } \mathrm{n}=89, \text { EUC } \\
\mathrm{n}=73)\end{array}$ & DSME & $\begin{array}{l}\text { DSME and } \\
\text { enhanced } \\
\text { usual care } \\
\text { (EUC) }\end{array}$ & $\begin{array}{l}\text { communit } \\
\text { y health } \\
\text { workers } \\
\text { (CHWs) } \\
\text { peer } \\
\text { leaders } \\
\text { (PLs) }\end{array}$ & $\begin{array}{l}\text { Clinical } \\
\text { HbA1c }(-) \\
\text { Psychosocial } \\
\text { Distress }(-) \\
\text { Social support }(+) \\
\text { DM knowledge }(+)\end{array}$ & $\begin{array}{l}6-18 \\
\text { months }\end{array}$ \\
\hline $\begin{array}{l}\text { (Paz- } \\
\text { Pacheco } \\
\text { et al., } \\
2017)\end{array}$ & $\begin{array}{l}\text { Prospecti } \\
\text { ve, } \\
\text { education } \\
\text { - } \\
\text { interventi } \\
\text { on trial }\end{array}$ & $\begin{array}{l}\mathrm{N}=19 \\
\text { (intervention } \\
\mathrm{n}=9 \quad \text { control } \\
\mathrm{n}=10 \text { ) }\end{array}$ & $\begin{array}{l}\text { DSME: } \\
\text { 1. Peer } \\
\quad \text { educator } \\
\text { DSME } \\
\text { content }\end{array}$ & $\begin{array}{l}\text { DSME } \\
\text { Program and } \\
\text { Standard } \\
\text { Care }\end{array}$ & $\begin{array}{l}\text { peer } \\
\text { educators }\end{array}$ & HbA1c level (-) & 3-6 months \\
\hline $\begin{array}{l}\text { (Albikaw } \\
\text { i et al., } \\
2016)\end{array}$ & RCT & $\begin{array}{l}\mathrm{N}=149 \\
\text { (intervention } \\
\mathrm{n}=76, \quad \text { control } \\
\mathrm{n}=73 \text { ) }\end{array}$ & $\begin{array}{l}\text { Diabetes Self } \\
\text { Efficacy } \\
\text { Intervention } \\
\text { Package }\end{array}$ & $\begin{array}{l}\text { DSEEIP: } \\
\text { Diabetes Self } \\
\text { Efficacy } \\
\text { Intervention } \\
\text { Package }\end{array}$ & $\begin{array}{l}\text { the DM } \\
\text { clinic } \\
\text { physicians }\end{array}$ & $\begin{array}{l}\text { Clinical } \\
\text { HbA1c }(-) \\
\text { Psychosocial } \\
\text { Depression }(-) \\
\text { Social support }(+) \\
\text { Knowledge of DM } \\
\text { management }(+) \\
\text { Distress }(-)\end{array}$ & $\begin{array}{l}2 \text { weeks-3 } \\
\text { months }\end{array}$ \\
\hline
\end{tabular}

management of diabetes, thereby reducing DMrelated mortality and morbidity and improving their quality of life. The main results of the program were a decrease in HbA1c, glucose, cholesterol, and LDL and to promote an increase in self-management behavior, quality of life, self-efficacy and self-management compliance(Nguyen et al., 2015). 
FiLDCare Project DSME/S. This program is the first diabetes treatment with a self-management modification specifically for type 2 Diabetes Mellitus patients. This program produces an improvement $n$ clinical and psychosocial status, namely the improvement of HbA1c, waist circumference, increased knowledge and compliance (Kumar S, Nayak RR, 2015).

Diabetes Self Efficacy Intervention Package. It is a package of self-efficacy interventions designed for patients with type 2 diabetes mellitus which emphasizes increasing self-efficacy and goal-setting skills to improve self-efficacy and to change people's behavior. DSEEIP can promote the level of self-care management behavior at two weeks and three months after intervention (Albikawi et al., 2016).

Traditional Education (TE) Canadian conversation maps (CMs). Traditional education from Canada specifically designed for patients with type 2 diabetes mellitus can improve clinical and psychosocial status, namely the improvement of HbA1c, waist circumference, increased knowledge and compliance (Adam, O'Connor, \& Garcia, 2018).

Education has a positive effect when it comes to improving the health status of the patients with type 2 diabetes. Twelve studies reported improvements in the clinical status of HbA1c. For example, a study by (Chai et al., 2018) revealed that the HbA1c levels among the participants decreased significantly $[7.20 \%(6.40 \%, 9.10 \%)]$ in the first and $[6.20 \%$ $(580 \%, 6.60 \%)]$ in the sixth month $\mathrm{P}<0.00$ after the educational intervention was given for six months. Several studies have shown there to be improvements in blood glucose status, cholesterol, lipid levels, LDL, BMI (Body Mass Index) blood pressure, waist circumference and body weight. For example, in the study conducted by (Chai et al., 2018), the weight loss was $(.11 .19 \pm 1.39 \mathrm{~kg}$ versus $(-0.61 \pm$ $2.04 \mathrm{~kg} ; P<0.05)$ in the group intervention to be compared with the control group.

In a study by (Chai et al., 2018), referring to patients in the intervention group, there was a significant reduction in $\mathrm{HbA1c}$ level and body weight in the follow-up examinations compared with the baseline examinations $(P<0.05)$. The HbA1c changes and body weight after 3 months were significantly greater in the intervention group than in the control group $(P<0.05)$. For both the intervention and control groups, there was a significant reduction in total cholesterol, LDL, and BMI in the follow-up examination $(P<0.05)$. In another study that was conducted(Ku \& Kegels, 2014), after a year of FiLD Self Care Management and Support intervention, the analysis of the median values showed a significant decrease in $\operatorname{HbA1c}(\mathrm{p}<0.001)$, waist circumference $(\mathrm{p}$ $=0.007)$ and waist base ratio $(\mathrm{p}<0.001)$.

Five studies reported that the results of the research related to improving the quality of life of people with type 2 diabetes. For example, in a study by (Kargar Jahromi, Ramezanli, \& Taheri, 2014), there was a significant difference between the two groups $(\mathrm{P}=0.012)$ after being given a diabetes self- management program intervention for 2 and 3 months. In other words, the training session increased the QOL score (Quality of Life) in the experimental group $(\mathrm{P}<0.001)$ compared to the control group $(\mathrm{P}=0.5)$. The study resulted in an intervention group that showed a statistically significant increase in self-efficacy related to diabetes and quality of life compared to the control group, as well as improvements in quality of life and medication adherence(Nguyen et al., 2015). Significant physical activity reported that the frequency and duration of activities was significantly and statistically higher among the patients assigned to the experiment compared to the patients in the control group; 7.0 1.0 vs. 4.07 .0 days / week ( $p=0.004)$ and 12060 vs. 30 60 minutes / day $(\mathrm{p}=0.001)$ (Abdulah, Hassan, Saadi, \& Mohammed, 2018). The proposal analysis of the study stated that there was significant increase in treatment compliance ( $p=0.001)$ and exercise adherence ( $\mathrm{p}<0.001)$ but a significant reduction in dietary compliance $(\mathrm{p}<0.001)(\mathrm{Ku} \&$ Kegels, 2014).

The research performed stated that there was an increase in knowledge in the first study session. After a 2-week evaluation, there was a significant increase in knowledge in the CMs group ( $p=0.0023$ ) (Adam et al., 2018). The findings from the study (Habibzadeh et al., 2017) indicated that a group discussion is an effective method for improving the self-management of diabetics (Paz-Pacheco et al., 2017). Furthermore, the use of the group discussion method can be an effective approach for holding active training sessions, for improving self-management and for facilitating the learning process in the real environment.

The study carried out, after a full year of FiLD Self Care Management and Education support, an analysis of the median scores that showed significant perceptual support from families and friends ( $p$ $<0.001$ ), a significant increase in the correct answers from the knowledge tests ( $p<0.001)$, the ability to perceive sugar control $(p=0.036)$, the ability to perceive diet control and exercise $(p=0.022)$, and the ability to perceive fear of the disease $(\mathrm{p}<0.001)(\mathrm{Ku}$ \& Kegels, 2014).

\section{DISCUSSION}

Type 2 diabetes mellitus is a type of diabetes that is characterized by an increase in blood sugar due to the decrease of insulin secretions by the pancreatic beta cells and / or impaired insulin function (insulin resistance)(Chai et al., 2018). Type 2 diabetes mellitus requires high-quality clinical care and the effective involvement of patients by improving their self-management skills. This is because diabetics experience problems related to the biological, psychological and social aspects of their life. Poorly controlled blood glucose leads to serious complications which will impose a large economic burden on the individual and on the healthcare system. 
The caring of patients with diabetes is of growing importance to the public health sector. For the proper control of diabetes mellitus, it is essential for the patients to actively participate in their own management such as having an appropriate diet, level of physical activity, blood glucose monitoring and adherence to medication. Professional health workers are responsible for providing clinical care for patients with type 2 diabetes mellitus. Some selfmanagement programs and support for diabetics are given to improve the patient's skills in managing their diabetes symptoms and / or risk factors.

Diabetes self-management (DSM) refers to the concept that each person systematically has to be involved in the management of their medical and nonmedical conditions (Abdulah et al., 2018). The assessment process is collaboratively conducted by a health care professional with the participant to identify their needs and potential self-management support strategies. The health care professional uses the information gleaned from the assessment to determine the appropriate educational and behavioral interventions, including enhancing the participant's problem-solving skills (Beck et al., 2018) (Chrvala et al., 2016).

Many leaders have participated in several programs such as DSME as they are professional nurses(Abdulah et al., 2018; Adam et al., 2018; Cai \& $\mathrm{Hu}, 2016$; Chai et al., 2018; García et al., 2014; Habibzadeh et al., 2017; Kargar Jahromi et al., 2014; $\mathrm{Ku}$ \& Kegels, 2014). The nurses collaborated with other health professionals, including endocrinologists, nutritionists, pharmacists, registered dietitians, community health workers (Azami et al., 2018; Kim et al., 2015), peer educators and one of them collaborated with community health workers (CHWs) (Paz-Pacheco et al., 2017; Spencer et al., 2018), a certificated nutritionist and a registered dietitian nutrition. There were also (RDN) (Yuan et al., 2014), physicians collaborated with (Albikawi et al., 2016) and one study was conducted by a multidisciplinary team from medicine, psychology and public health (Rusdiana, M., \& R., 2018).

The usual self-management education activities aim to provide information about the disease process, its pathophysiology and instructions about selfmanagement behavior which can include diet, physical activity, monitoring, medication, risk reduction, problem solving and coping. Several published individual articles and a meta-analysis of the tests evaluating the effectiveness of DSME have demonstrated the efficacy of DSME for diabetics in terms of improving glycemic control, knowledge, selfmanagement behavior, the psychological aspects and self-management behavior. The arrangements, techniques and types of interventions used in the DSME program vary and involve a combination of a number of providers including at least three of the following: medical specialists, dieticians, psychologists, managers and pharmacists apart from primary care doctors, nurses and community-based health workers.
Several different types of diabetes self-care education management programs have their own innovations. A Problem Based Learning (PBL) program is a program based on specific problem learning in patients with type 2 diabetes mellitus. This program can reduce anxiety and depression, decrease the fasting blood glucose levels and HbA1c, and improve the diabetes self-management and health of patients with type 2 diabetes mellitus (Chai et al., 2018). Nurse-led DSME interventions are an educational program led by nurses as educators. This is done by educating the patients related to the selfmanagement and self-care of type 2 diabetes mellitus patients (Azami et al., 2018). The Self-Help Intervention Program was designed for diabetes management. This intervention is designed to help type 2 diabetes mellitus patients in carrying out self care independently. The aim of this program is to help the patients to achieve better glycemic control and to bring back their confidence in the management of diabetes mellitus (Kim et al., 2015).The Diabetes Self Efficacy Intervention Package is a package of selfefficacy interventions designed for patients with type 2 diabetes mellitus that emphasizes on increasing self-efficacy to change the person's behavior (Albikawi et al., 2016). Traditional Education (TE) Canadian conversation maps (CMs) are a form of traditional education from Canada specifically designed for patients with type 2 diabetes mellitus that can improve the patient's clinical and psychosocial status (Adam et al., 2018).

The DSME study was carried out for more than 6 months and up to 1 year in order to have a positive impact on type 2 diabetes mellitus. Generally, the results of the DSME/S program showed positive results. There were no research reports that stated the patient's condition was getting worse after participating in the DSME/S program. Twelve studies reported that the DSME/S program had a positive impact on the biological aspects, namely a statistically significant decrease in the HbA1c levels. Two studies reported a decrease in the glucose levels of patients with type 2 diabetes. Other studies showed an improvement in the clinical outcomes related to total cholesterol, LDL, severe body, blood pressure, BMI (Body Mass Index) and waist circumference.

The basic targets in the treatment of T2DM are the normalization of blood glucose, blood pressure control and lipid management. Studies have shown that good glycemic control is associated with a significant reduction in the risk of many complications (Chai et al., 2018). The control of diabetes is affected by both lifestyle factors and pharmacological treatments. The management of diabetes is largely the responsibility of those affected. The role of education is to improve the patients' understanding of diabetes mellitus and to enhance their self-management practices. Meanwhile, active collaboration with the caregivers can improve their clinical outcomes and quality of life.

The administration of DSME/S resulted in a simple but significant weight loss, which in turn led to a 
significant reduction in $\mathrm{HbA} 1 \mathrm{c}$ and blood pressure (Azami et al., 2018). There are numerous factors that can lead to changes in these variables, but lifestyle modifications are the key factor in the management of diabetes. Changes in lifestyle and dietary habits may have led to a weight reduction over time.

Similarly, the mental health of patients with diabetes cannot be ignored. Patients with type 2 diabetes mellitus are closely related to psychological problems, which has an impact on their health status and quality of life. Some studies have shown that both depressive disorders and anxiety disorders have a close relationship with type 2 diabetes (Busch et al., 2015). The reality is that diabetes affects the lives of patients. The mere presence of diabetes worsens a person's quality of life (QoL). When diabetes coexists with other chronic diseases, the effect is even worse (Trikkalinou, AK, \& A, 2017).

Studies have reported that patients who went on the DSME/S program after a minimum of two months had a positive impact on improving the patients' quality of life (Azami et al., 2018; Chai et al., 2018; García et al., 2014; Kargar Jahromi et al., 2014; Kim et al., 2015). Besides, distress in the patients also decreased significantly (Albikawi et al., 2016; Spencer et al., 2018). This is supported by the existence of support systems, family and social support that can increase motivation, empowerment, knowledge and self-efficacy. This is so then the patients with type 2 diabetes are able to implement diabetes care management independently. For example, the patient adheres to the treatment and control of glycemia and their routine exercise activities.

These results demonstrated that the psychosocial intervention was very effective in relation to the treatment of T2DM patients with depression and anxiety. In addition, the improvement of anxiety and depression can also indirectly affect blood glucose. The improvement of depression and anxiety plays an active role in the control of blood glucose. As it is known, there are many factors influencing the level of blood glucose. There is no denying that the improvement of blood glucose has been impacted by professional education. Through the systematic learning of diet, physical activity, diabetic medications and complications, the patients have gained a better understanding from their previous state. They have become capable of tackling diabetes and they are also confident when it comes to the proper self-management of diabetes.

Pathophysiologically, there is a relationship between depression and blood glucose level. Chronic stress activates the hypothalamus - pituitary adrenal axis (HPA-axis) and the sympathetic nervous system (SNS), increasing the production of cortisol in the adrenal cortex and the production of adrenalin and noradrenalin in the adrenal medulla (Kyrou \& Tsigos, 2009). Chronic hypercortisolemia and prolonged SNS activation promotes insulin resistance and visceral obesity, and it leads to metabolic syndrome and DM2 (Chrousos, 2009). Excess cortisol disturbs the neurogenesis in the hippocampus, which is a region involved in depression as well as in DM2 (Moulton, Costafreda, Horton, Ismail, \& Fu, 2015). Seeing the negative effects caused by psychological problems that can worsen the condition of patients with type 2 diabetes mellitus, self-efficacy (expectations of success and expected results) and social support from other people is needed, such as support from one's spouse, family, community and health workers. This shows that the DSME/S program was intensively very significant for the psychological and social aspects of type 2 diabetes mellitus patients.

Quality diabetes care must include the involvement of DSME/S because it is beneficial to the biological, psychological, and social aspects of the patient. An effective DSME must integrate practical and feasible educational interventions that can be implemented in a variety of settings. Our results show that DSME has the potential to achieve a clinically significant A1C reduction, reduce psychological stress and increase social support by reducing the risk of complications produced. Health workers must refer their patients to diabetes self-management education using a diabetes education algorithm to improve the patient's health status.

\section{CONCLUSION}

The findings of our review showed that DSME had a positive impact on the biological, psychological and social aspects of type 2 diabetes mellitus. For the biological aspects, it can decrease $\mathrm{HbA1c}$, blood glucose, LDL, cholesterol, blood pressure, weight and waist circumference. For the psychological aspects, it can reduce distress, anxiety and increase self-efficacy, and self-empowerment. The social aspects of the DSME/S program can increase the social and family support so then there is an improvement in the motivation, knowledge and self-management behavior of diabetes mellitus.

There are some limitations regarding this systematic review. There is no unique protocol for evaluating the journals homogeneously, but we observed the differences in the sample dimensions, in the procedures for recruiting / selecting the journals and in the inclusion and exclusion criteria for the patients. The journal literature that we have included in this systematic review are not directed at the holistic aspects of how the researchers sorted through the sub-categories of biological, psychological and social aspects so then the readers can deeply understand the benefits of the DSME program in all three aspects.

\section{REFERENCES}

Abdulah, D. M., Hassan, A. B., Saadi, F. S., \& Mohammed, A. H. (2018). Impacts of selfmanagement education on glycaemic control in patients with type 2 diabetes mellitus. Diabetes and Metabolic Syndrome: Clinical Research and Reviews, 12(6), 969-975. https://doi.org/10.1016/j.dsx.2018.06.007 
Adam, L., O'Connor, C., \& Garcia, A. C. (2018). Evaluating the Impact of Diabetes SelfManagement Education Methods on Knowledge, Attitudes and Behaviours of Adult Patients With Type 2 Diabetes Mellitus. Canadian Journal of Diabetes,

1-8. https://doi.org/10.1016/j.jcjd.2017.11.003

Albikawi, Z. F., Petro-Nustas, W., \& Abuadas, M. (2016). Self-care Management Intervention to Improve Psychological Wellbeing for Jordanian Patients with Type Two Diabetes Mellitus. Issues in Mental Health Nursing, 37(3), 190-201. https://doi.org/10.3109/01612840.2015.11221 18

Azami, G., Soh, K. L., Sazlina, S. G., Salmiah, M. S., Aazami, S., Mozafari, M., \& Taghinejad, H. (2018). Effect of a Nurse-Led Diabetes Self-Management Education Program on Glycosylated Hemoglobin among Adults with Type 2 Diabetes. Journal of Diabetes Research, 2018, 1-12.

Beck, J., Greenwood, D. A., Blanton, L., Bollinger, S. T., Butcher, M. K., Condon, J. E., ... Wang, J. (2018). 2017 National Standards for Diabetes SelfManagement Education and Support. Diabetes Educator, 44(1), 35-50. https://doi.org/10.1177/0145721718754797

Busch, M., Kahl, K. G., Schweiger, U., Correll, C., Conrad, M., Bauer, M., \& Schwarz, P. (2015). Depression , anxiety disorders, and metabolic syndrome in a population at risk for type 2 diabetes mellitus, 1 , 1-7. https://doi.org/10.1002/brb3.306

Cai, C., \& Hu, J. (2016). Effectiveness of a Family-based Diabetes Self-management Educational Intervention for Chinese Adults With Type 2 Diabetes in Wuhan, China. Diabetes Educator, 42(6), 697-711. https://doi.org/10.1177/0145721716674325

Chai, S., Yao, B., Xu, L., Wang, D., Sun, J., Yuan, N., ... Ji, L. (2018). The effect of diabetes self-management education on psychological status and blood glucose in newly diagnosed patients with diabetes type 2. Patient Education and Counseling, 101(8), 1427-1432.

https://doi.org/10.1016/j.pec.2018.03.020

Chrousos, G. P. (2009). reviews Stress and disorders of the stress system. Nature Publishing Group, $5(7)$, 374-381. https://doi.org/10.1038/nrendo.2009.106

Chrvala, C. A., Sherr, D., \& Lipman, R. D. (2016). Patient Education and Counseling Diabetes selfmanagement education for adults with type 2 diabetes mellitus: A systematic review of the effect on glycemic control. Patient Education and Counseling, 99(6), 926-943. https://doi.org/10.1016/j.pec.2015.11.003

Costa, D. S. et al. (2016). Prevalence of subclinical hypercortisolism in type 2 diabetic patients from the Rio de Janeiro Type 2 Diabetes Cohort Study. of Diabetes and Its Complications, 30(6), 10321038.

Farhangi, M. A. et al. (2017). A randomized controlled trial on the efficacy of resistant dextrin, as functional food, in women with type 2 diabetes: Targeting the hypothalamic-pituitary-adrenal axis and immune system. Clinical Nutrition, 37(4), 1216-1223.

García, A. A., Brown, S. A., Horner, S. D., Zuñiga, J., \& Arheart, K. L. (2014). Home-based diabetes symptom self-management education for Mexican Americans with type 2 diabetes. Health Education Research, 30(3), 484-496. https://doi.org/10.1093/her/cyv018

Habibzadeh, H., Sofiani, A., Alilu, L., \& Gillespie, M. (2017). The effect of group discussion-based education on self-management of adults with type 2 diabetes mellitus compared with usual care: A randomized control trial. Oman Medical Journal, 32(6), 499-506. https://doi.org/10.5001/omj.2017.95

Kargar Jahromi, M., Ramezanli, S., \& Taheri, L. (2014). Effectiveness of Diabetes Self-Management Education on Quality of Life in Diabetic Elderly Females. Global Journal of Health Science, 7(1), 1015. https://doi.org/10.5539/gjhs.v7n1p10

Kementrian Kesehatan RI. (2018). Hasil Utama Riset Kesehatan Dasar Jawa Timur 2018. Jakarta: Badan Penelitian Dan Pengembangan Kesehatan, Kementrian Kesehatan Republik Indonesia, 1-82.

Kim, M. T., Kim, K. B., Huh, B., Nguyen, T., Han, H. R., Bone, L. R., \& Levine, D. (2015). The Effect of a Community-Based Self-Help Intervention: Korean Americans With Type 2 Diabetes. American Journal of Preventive Medicine, 49(5), 726-737. https://doi.org/10.1016/j.amepre.2015.04.033

Ku, G. M. V., \& Kegels, G. (2014). Effects of the First Line Diabetes Care (FiLDCare) self-management education and support project on knowledge, attitudes, perceptions, self-management practices and glycaemic control: A quasi-experimental study conducted in the Northern Philippines. BMJ Open, 4(8). https://doi.org/10.1136/bmjopen2014-005317

Kumah, E., Sciolli, G., Toraldo, M. L., \& Murante, A. M. (2018). The diabetes self-management educational programs and their integration in the usual care : A systematic literature review. Health Policy, 122(8), 866-877. https://doi.org/10.1016/j.healthpol.2018.06.003

Kumar S, Nayak RR, D. S. (2015). Effectiveness Jacobson's progressive muscle relaxation technique (PMRT) to relieve anxiety among alcoholic patients MHI, SCB, Cuttack, Odisha.J Nurs Health Sci, 4, 1-6.

Kyrou, I., \& Tsigos, C. (2009). Stress hormones: physiological stress and regulation of metabolism, 787-793. https://doi.org/10.1016/j.coph.2009.08.007

Moulton, C. D., Costafreda, S. G., Horton, P., Ismail, K., \& Fu, C. H. Y. (2015). Meta-analyses of structural regional cerebral effects in type 1 and type 2 diabetes. https://doi.org/10.1007/s11682-0149348-2

Nguyen, T., Levine, D., Kim, K. B., Huh, B., Bone, L. R., Kim, M. T., \& Han, H.-R. (2015). The Effect of a 
Community-Based Self-Help Intervention. American Journal of Preventive Medicine, 49(5), 726-737.

https://doi.org/10.1016/j.amepre.2015.04.033

Paz-Pacheco, E., Sandoval, M. A., Ardena, G. J. R., Paterno, E., Juban, N., Lantion-Ang, F. L., ... Bongon, J. (2017). Effectiveness of a community-based diabetes self-management education (DSME) program in a rural agricultural setting. Primary Health Care Research and Development, 18(1), 3549. https://doi.org/10.1017/S1463423616000335

Rusdiana, M., S., \& R., A. (2018). The effect of diabetes self-management education on Hba1c level and fasting blood sugar in type 2 diabetes mellitus patients in primary health care in binjai city of north Sumatera, Indonesia. Open Access
Macedonian Journal of Medical Sciences, 6(4), 715718. https://doi.org/10.3889/oamjms.2018.169 Spencer, M. S., Kieffer, E. C., Sinco, B., Piatt, G., Palmisano, G., Hawkins, J., ... Funnell, M. (2018). Outcomes at 18 Months From a Community Health Worker and Peer Leader Diabetes SelfManagement Program for Latino Adults, 1-9.

Trikkalinou, A., AK, P., \& A, M. (2017). Type 2 diabetes and quality of life. World Journal of Diabetes, $8(4)$, 120-129.

Yuan, C., Lai, C. W., Chan, L. W., Chow, M., Law, H. K., \& Ying, M. (2014). The effect of diabetes selfmanagement education on body weight, glycemic control, and other metabolic markers in patients with type 2 diabetes mellitus. J Diabetes Res, 2014, 789761. https://doi.org/10.1155/2014/789761 